\title{
Evaluation of Crack Potency in the Bituminous Concrete using Fracture Mechanics Parameters
}

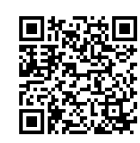

\author{
Suman SK* and Shrikant \\ Department of Civil Engineering, NIT Patna, Patna, Bihar, India
}

Submission: September 04, 2020; Published: September 21, 2020

*Corresponding author: Suman SK, Department of Civil Engineering, NIT Patna, Patna, Bihar, India

\begin{abstract}
Fatigue cracking is very critical among all types of distresses in pavements once the fatigue crack start in pavement it led to fast pavement deterioration and thus reduced the life of pavement and quality of riding on pavement. Thus, to control such distress it is necessary to understand the mechanics behind such crack initiation and propagation and to find the fracture parameters to choose best mixture to resist the failure. There are various methods to understand the fracture properties of the bituminous concrete (BC) mix. This paper describes the semi-circular bending test for BC mix, which was designed to be very effective, and user friendly. This method is adopted because it simulates the field conditions and its availability. Semi-circular samples of forty-eight were prepared out of which half was made of unmodified bitumen and the rest were made of plastic modified bitumen. These all samples were then tested at different loading rates and value of load at each deflection is measured. Two fracture parameters like fracture energy and stress intensity factor are evaluated. The plastic modified bituminous concrete shows that the value of energy is increased 2 to 3 times than the unmodified bituminous concrete at intermediate temperature. Hence, plastic modified bituminous concrete has the greater cracking resistance potential.
\end{abstract}

Keywords: Fracture energy; Stress intensity factor; Plastic modified bituminous concrete; Semi-circular bending

\section{Introduction}

Crack in the pavement influences the long-term durability of the bituminous concrete. The highways maintenance and management could not be done without considering the characteristics and fracture resistance of the bituminous mix during the life of the pavement. The life of the pavement depends upon the fracture resistance and the characteristics of bituminous mix, which is indirectly, affect the pavement maintenance and the management. Crack in the pavement may occur due to the low temperature, fatigue and moisture [1]. Thus, it is very necessary to analyses the cracking behaviour of bituminous concrete. The cracking behaviour of bituminous mix were studied by the various researchers at the low temperature using linear elastic fracture mechanics. But in India, the temperature in the most of the area found to be moderate and on the other hand continues use of plastic in the construction of road; require a complete study on these two aspects. The aim of this paper is to estimate fracture parameters of bituminous concrete at the moderate temperature and at different loading rates with or without modification of plastic.

Ozer Hasan (2009) studied about the use of recycles materials in the construction of bituminous concrete (BC) pavement that improves the sustainability of $\mathrm{BC}$ pavement because it reduces the initial of cost of construction [2]. The fracture resistance of $\mathrm{BC}$ mix was obtained by conducting the semi-circular bending test and flexibility index. It was calculated from load-displacement profile obtained during the test. The result shows that flexibility index is the best parameter to understand the fatigue failure of BC pavement in the field. Zegeye (2011) carried out studies on four SCB samples which was prepared with different diameters such as $76.4 \mathrm{~mm}, 101 \mathrm{~mm}, 147 \mathrm{~mm}$, and $296 \mathrm{~mm}$. Every diameter size sample was notched to obtain notch to radius ratio $0,0.05,0.2$. The test result shows that less specimen crack start from far end in larger diameter notch. Strength was decreased as the diameter of samples increased thus sample having diameter above $150 \mathrm{~mm}$ is not of any practical use. Krishna Saha Gourab (2016) investigated fracture behavior of DBM, open-graded and gap graded using SCB test. Fracture parameters were obtained from load-displacement profile and these parameters were used to evaluate the fracture damage. The damage model was also developed based on energy and material behavior. The results show that energy dissipation was nearly 2 times more than conventional mix. Pirmohammad S. (2012) studied the effects of temperature and loading mode on fracture resistance of $\mathrm{BC}$ mix under constant loading. The 
result shows that under different loading mode and temperature fracture resistance first increase and then start decreasing below fix temperature i.e. $20^{\circ} \mathrm{C}$. The minimum value of fracture resistance under mixed mode is said to be the fracture index. The fracture index was used further for crack growth analysis in the $\mathrm{BC}$ mix. The test result also shows that at the low temperature modified mix shows more fracture resistance than normal mix. Krishna Saha Gourab (2017) investigated fracture behavior of DBM for open-graded and gap graded using SCB test. Fracture parameters were obtained from load-displacement profile and these parameters were used to evaluate the fracture damage [3]. The damage model was also developed based on energy and material behavior.

There are various fracture test configurations, which were used by many researchers to determine the fracture parameters. Testing methods are single notch beam, semi-circular bending, indirect tensile strength and disk shaped tension compact test. These all test configurations have their own advantages and disadvantages. Semi-circular bending test is used to analyse mixed mode failure. In the linear elastic fracture mechanics approach stress intensity factor is considered as the main factor for describing the fracture behaviour of the elastic material. While in the viscos-elastic material such as bituminous concrete fracture energy better represents the resistance to the crack instead of stress intensity factor.

\section{Fracture Energy}

One crucial parameter when addressing cracking resistance is the fracture energy, which is the energy required to produce a unit surface area crack. In asphalt specimen, the load initially creates an elastic strain that may trigger a fracture. If this happens, the energy is then used to propagate the cracking and deform the specimen [4-5]. It is very difficult to measure the fracture parameters of the bituminous concrete because of viscos-elastic nature. Normalized fracture energy was calculated by area of load-deflection diagram. The load-deflection curve was formed from the values of load and deflection noted down from machine during testing. Fracture energy was normalized by dividing the area of load-deflection by area of ligament of specimen which is equal to $(w-a) t$. Normalization of energy decrease the effect of notch length and size of specimen.

$$
G_{f}=\frac{w_{f}}{A_{s}}
$$

Where, $G_{f}=$ fracture energy $\left(\mathrm{J} / \mathrm{m}^{2}\right), W_{f}=$ fracture work = $\int F \mathrm{du}, \mathrm{F}=$ force, $A_{s}=$ area of ligament

Thus, fracture energy represents the fracture work and in other words energy dissipated in resisting the fracture in the bituminous concrete. In this work this concept will be used to determine the fracture properties of bituminous concrete at different loading rates and bitumen contents with or without plastic modification.

\section{Stress Intensity Factor}

During the testing of specimens, load and deflection values are obtained and these values are plotted and thus, a load-deflection curve is obtained. ASTM also presented the standard loaddeflection curve as mentioned in the Figure 1. Load-deflection curve indicates that value of load is increased linearly with deflection. Thus, the value of the stress intensity factor increases as the load increase and as the load reaches to the maximum value crack is initiated and value of stress intensity factor become maximum.

$$
\begin{aligned}
& K_{i c}=\sigma^{\max * f(a / w)} \sqrt{\Pi} \mathrm{a} \\
& f\left(\frac{a}{w}\right)=-0.623+29.29\left(\frac{a}{w}\right) \wedge 2-171.2\left(\frac{a}{w}\right) \wedge 3+457.1\left(\frac{a}{w}\right) \wedge 4-561.2\left(\frac{a}{w}\right) \wedge 5+265.54\left(\frac{a}{w}\right) \wedge 6 \\
& \sigma^{\max }=4.263 * \frac{F^{\max }}{D t}
\end{aligned}
$$

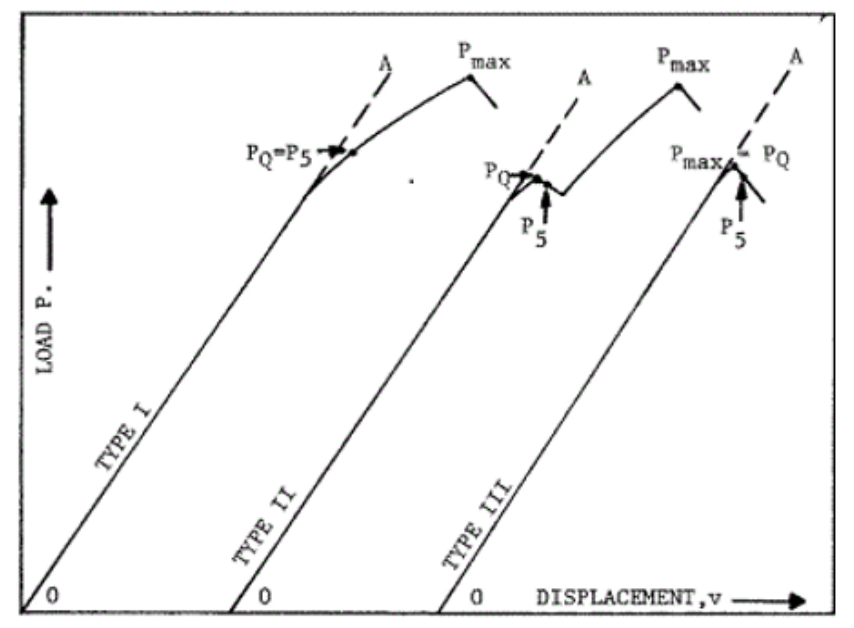

Figure 1: ASTM Standard Load-Deflection Diagram. 


\section{Civil Engineering Research Journal}

Since 1970 concept of fracture energy and stress intensity factor is used for the evaluation of fracture properties of bitumen mix. M. Fakhria et. al. studied the effect of moderate temperature and void ratio on the fracture energy. Ozer Hasan studied that the use of recycle materials in the construction of bituminous concrete pavement improves the sustainability of pavement [6-7]. However, literature study shows that mixed mode failure of plastic modified bituminous concrete at intermediate temperature rarely investigated.

\section{Materials}

Mainly three types of crushed aggregates was taken in this work namely coarse aggregate $20 \mathrm{~mm}$ passing (CA1), coarse aggregate $10 \mathrm{~mm}$ passing (CA2) and fine aggregate (sand -zone III). Cement (PPC) is used as the filler. Properties of coarse aggregates indicated in the Table 1. Grading system for bituminous concrete (BC) is presented in the Table 2 as per Ministry of road transport and highways (MORTH) specifications.

Table 1: Properties of aggregate.

\begin{tabular}{|c|c|c|}
\hline Properties & Observed value & MORTH prescribed value \\
\hline Aggregate crushing Strength value & $18.39 \%$ & Max- $30 \%$ \\
\hline Durability using Na2SO4 & $12 \%$ & 5 cycles Max $-12 \%$ \\
\hline Water absorption & 1.24 & Max $-2 \%$ \\
\hline Striping value & $98 \%$ & Minimum retained coating $95 \%$ \\
\hline Loss Angeles Abrasion value & $17.56 \%$ & Max- $40 \%$ \\
\hline Aggregate Impact value & $12.84 \%$ & Max- $30 \%$ \\
\hline
\end{tabular}

Table 2: Blending result of aggregates.

\begin{tabular}{|c|c|c|c|c|c|c|}
\hline Sieve(mm) & $\begin{array}{c}\text { Percentage passing } \\
\text { (CA1) (29\%) }\end{array}$ & $\begin{array}{c}\text { Percentage pass- } \\
\text { ing (CA2) (50\%) }\end{array}$ & $\begin{array}{c}\text { Percentage } \\
\text { passing (FA) } \\
\mathbf{( 1 9 \% )}\end{array}$ & $\begin{array}{c}\text { Percentage pass- } \\
\text { ing (Filler) (2\%) }\end{array}$ & $\begin{array}{c}\text { Combined Grada- } \\
\text { tion (100\%) }\end{array}$ & $\begin{array}{c}\text { Target } \\
\text { range }\end{array}$ \\
\hline 26.5 & 94.9 & 100 & 100 & 100 & 98.47 & 100 \\
\hline 19 & 69.34 & 100 & 100 & 100 & 90.8 & $90-100$ \\
\hline 13.5 & 22.21 & 98.1 & 100 & 100 & 75.65 & $56-88$ \\
\hline 4.75 & 0.57 & 10.3 & 95 & 100 & 21.88 & $16-36$ \\
\hline 2.36 & 0 & 2 & 66.2 & 99 & 12.97 & $4-19$ \\
\hline 0.3 & 0 & 0 & 17.8 & 92.2 & 4.51 & $2-10$ \\
\hline 0.075 & 0 & 0 & 11.4 & 87 & 3.45 & $0-8$ \\
\hline
\end{tabular}

\section{Bitumen}

Bitumen as binding material of $60 / 70$ penetration grade (VG30 viscosity grade) is used for preparation of mix. Properties of bitumen are shown in the Table 3.

Table 3: Properties of bitumen.

\begin{tabular}{|c|c|c|}
\hline Properties & Result & Ranges \\
\hline Penetration value & $63 \mathrm{~mm}$ & $63 \mathrm{~mm}$ \\
\hline Specific gravity & 1 & $0.98-1.02$ \\
\hline Softening point & $48.25^{\circ} \mathrm{C}$ & $40-60{ }^{\circ} \mathrm{C}$ \\
\hline Ductility value & $77.50 \mathrm{~cm}$ & Min $40 \mathrm{~cm}$ \\
\hline Viscosity value & $50.1 \mathrm{sec}$ & -- \\
\hline Flash Point & $280{ }^{\circ} \mathrm{C}$ & $>65-175^{\circ} \mathrm{C}$ \\
\hline Fire Point & $302{ }^{\circ} \mathrm{C}$ & \\
\hline
\end{tabular}

\section{Plastic}

The plastic waste shredded to the size varying between $2.36 \mathrm{~mm}$ and $4.75 \mathrm{~mm}$ is used to coat the aggregate surface by dry process. This shredded plastic waste is added over hot aggregate $\left(170^{\circ} \mathrm{C}\right)$ with constant mixing to give a uniform distribution.

\section{Preparation of Mix}

Bituminous concrete mix is prepared with and without plastic modified. A specimen of size $150 \mathrm{~mm}$ diameter and $50 \mathrm{~mm}$ thickness is prepared in modified Marshal Mould. The graded materials are heated to temperature of 170 to $190^{\circ} \mathrm{C}$. The bitumen binder is heated to temperature $120-165^{\circ} \mathrm{C}$. The mixing temperature for $\mathrm{VG} 30$ is $160^{\circ} \mathrm{C}$ and compacting temperature is $149^{\circ} \mathrm{C}$. Mix was poured in the mould and compacted by hammer at recommended temperature, by applying 75 blows on each side of specimen. After compaction, the specimen was allowed to cool down to the room temperature. In order to prepare the plastic modified specimens same procedure was followed but $8 \%$ (by the weight of bitumen) shredding plastic was added to the heated aggregate. Prepared specimens were drilled concentrically with the diamond drill of $16 \mathrm{~mm}$ diameter. In order to obtain the semicircular specimen, the drilled specimens were used to cut along diametrically. A notch of $10 \mathrm{~mm}$ length was also cut in each semicircular specimen Figure 2 \& Figure 3. 


\section{Civil Engineering Research Journal}

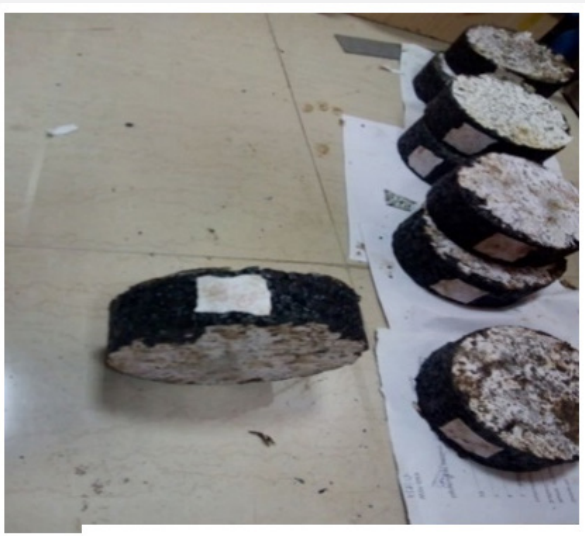

Figure 2: Specimens.

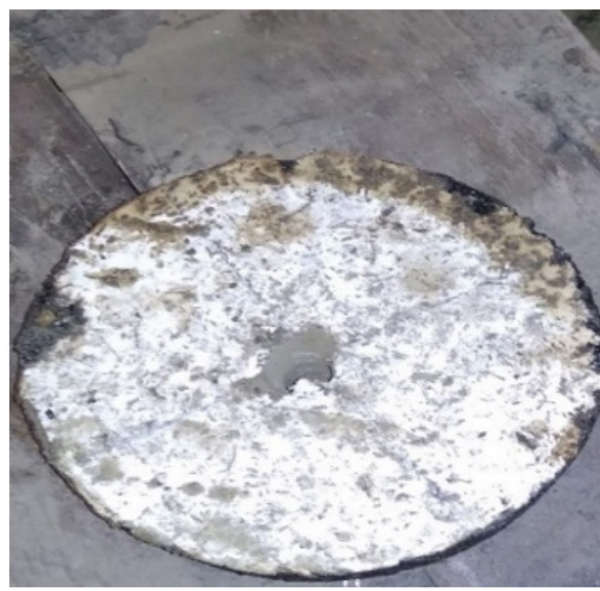

Figure 3: Drilled Specimen

\section{Testing Procedure}

Initially, the two supports made of concrete were placed 120 $\mathrm{mm}$ apart on the circular plate of machine. Then after, specimen was placed on these two supports, the marked points on the specimen were exactly meeting with the inner face of supports thus, clear span of $120 \mathrm{~mm}$ were obtained. A strip of small width was placed exactly in the same line of notch (so as to obtain the predefined crack path) on top of specimen in order to convert load into point load. Thereafter, load plunger $(50 \mathrm{~mm})$ were placed on the top of the strip. The strain gauge was calibrated and set on the circular plate of machine because plate move with same amount as deflection Thereafter, machine was started and set the initial reading of load and deflection zero. The load rate was first set at the $1.25 \mathrm{~mm} / \mathrm{min}$, value of load and corresponding value of deflection were depicted on the display. As the load was increased the specimen start store the energy, after reaching the load up to maximum value at which specimen start cracking, the machine was stop [8-10]. In order to understand the effect of loading rate on the energy stored in the specimen, second specimen of same bitumen content was tested at different loading rate i.e.
$1.5 \mathrm{~mm} / \mathrm{min}$ and same procedure as above was followed. Testing arrangement is shown in Figure 5 and crack shown in Figure 6.

\section{Results and Discussions}

\section{Fracture energy of unmodified bituminous concrete (UMBC)}

Semi-circular bending test is performed on the bituminous mix samples. Samples consists of bitumen content from $4.5 \%$ to $6 \%$ with increment of $0.5 \%$ in the mix and tested at two rate of loading $1.25 \mathrm{~mm} / \mathrm{min}$ and $1.5 \mathrm{~mm} / \mathrm{min}$. Observed load - deflections data are applied to plot graphs for determination of area to be used in fracture energy. Load-deflection graphs for unmodified bituminous concrete (UMBC) are shown in Figures 7-14. Fracture energy is determined using Eqn.1 is tabulated in the Table 4. The value of fracture energy increases with increase of bitumen content up to bitumen content $5 \%$ then after decreases for both the rate of loading. Similar trend has been also found by the Rodrigo et. al. The value of fracture energy is increased by about two times as the loading rate increases from the $1.25 \mathrm{~mm} / \mathrm{min}$ to the $1.5 \mathrm{~mm} / \mathrm{min}$. 


\section{Civil Engineering Research Journal}

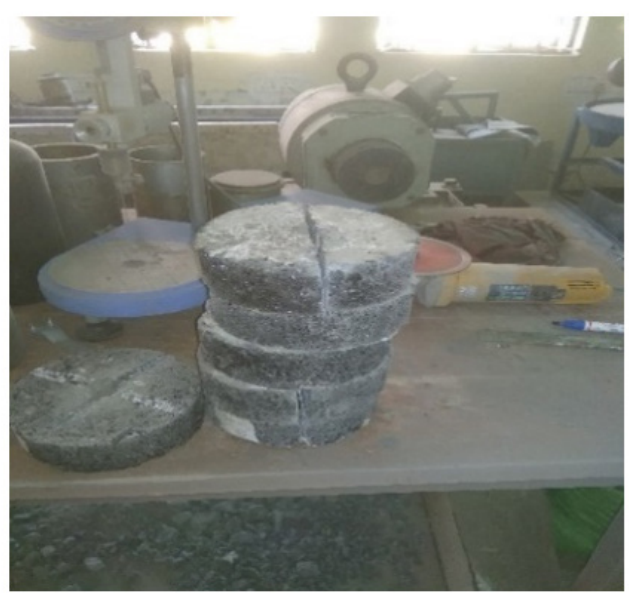

Figure 4: Semi-circular Specimens.

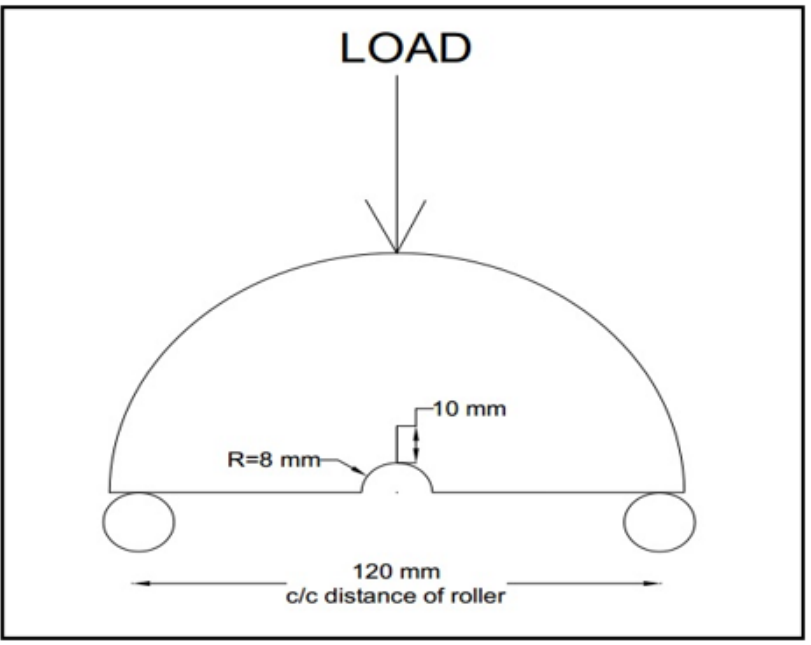

Figure 5: Testing of Specimen.

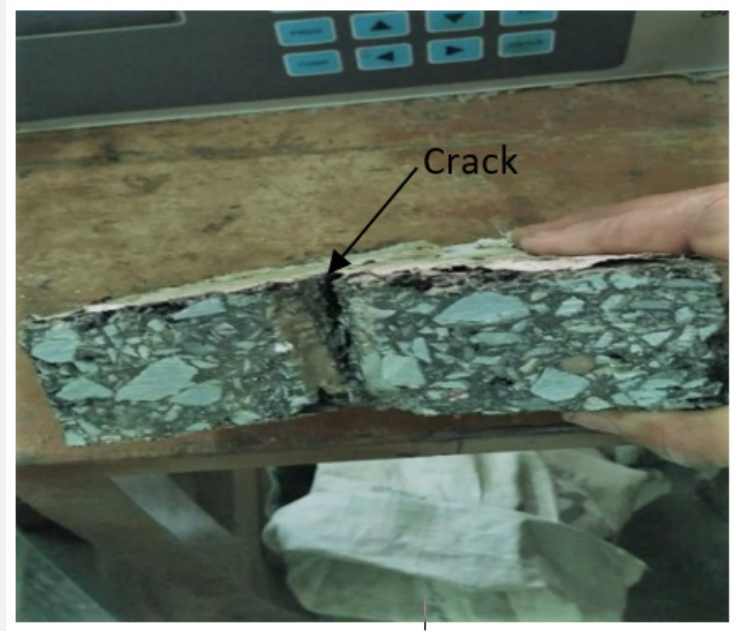

Figure 6: Cracked specimens. 


\section{Civil Engineering Research Journal}

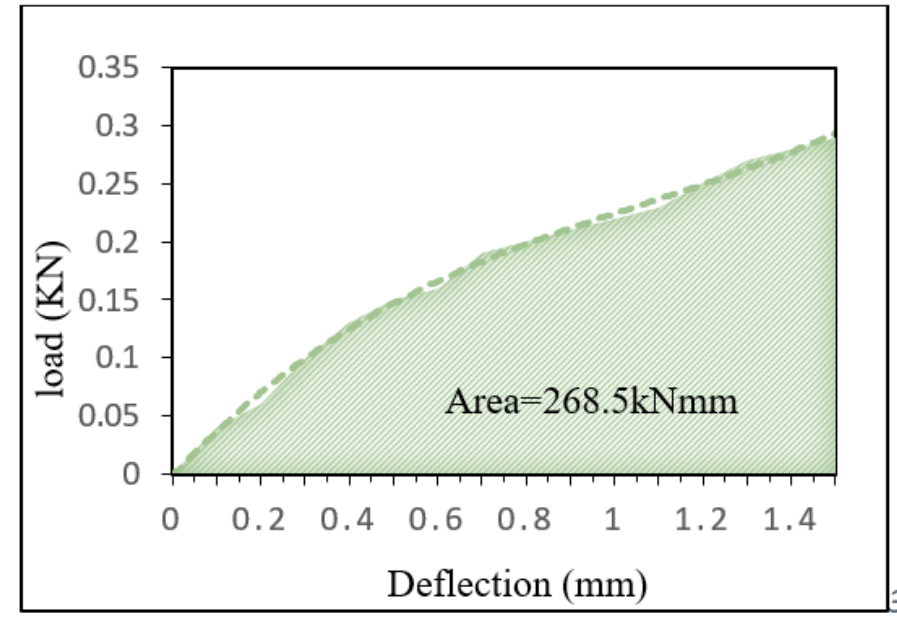

Figure 7: Load-deflection at BC $4.5 \% \& 1.25 \mathrm{~mm} / \mathrm{min}$.

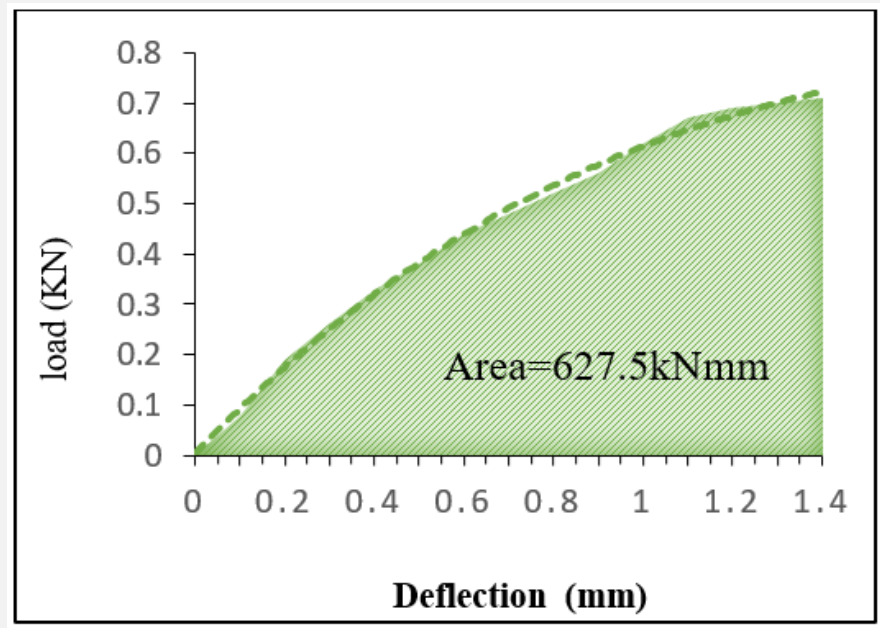

Figure 8: Load-deflection at BC4.5\% \& $1.5 \mathrm{~mm} / \mathrm{min}$.

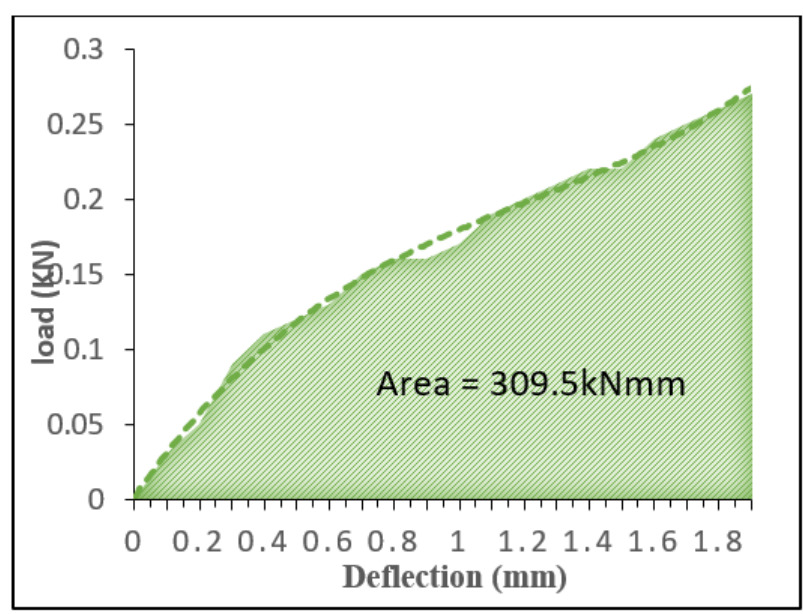

Figure 9: Load-deflection at BC5 \% \& $1.25 \mathrm{~mm} / \mathrm{min}$. 


\section{Civil Engineering Research Journal}

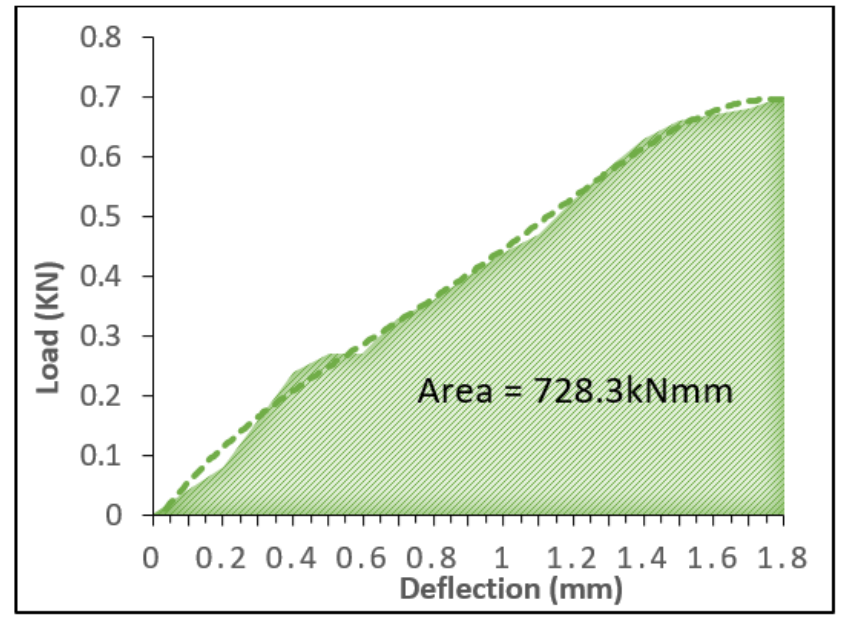

Figure 10: Load-deflection at BC $5 \%$ \& $1.5 \mathrm{~mm} / \mathrm{min}$.

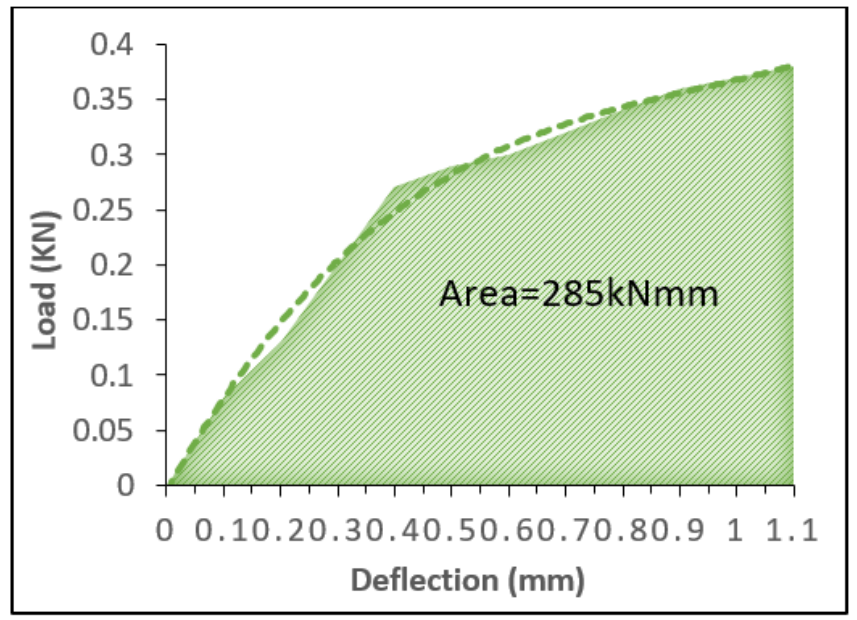

Figure 11: Load-deflection at BC5.5\% \& $1.25 \mathrm{~mm} / \mathrm{min}$.

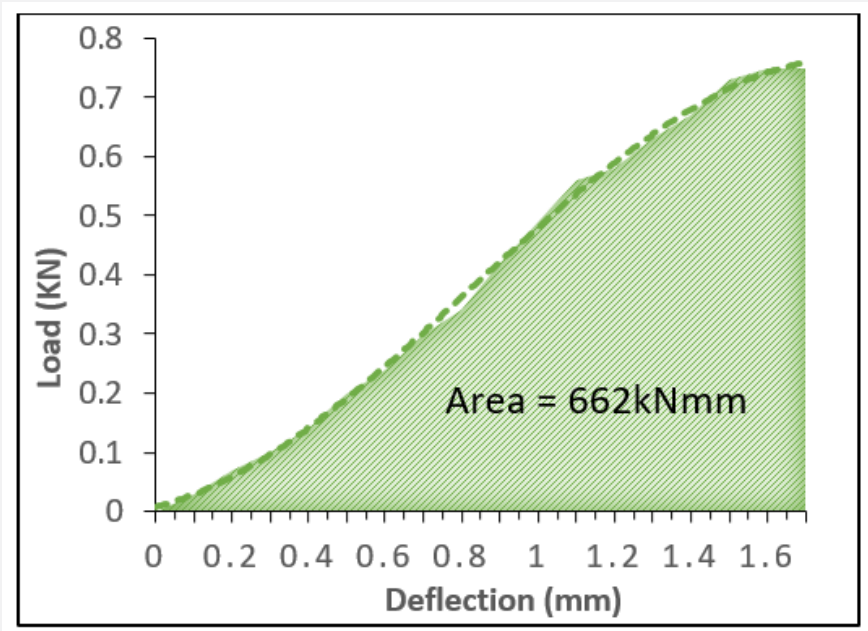

Figure 12: Load-deflection at BC $5.5 \%$ \& $1.5 \mathrm{~mm} / \mathrm{min}$. 


\section{Civil Engineering Research Journal}

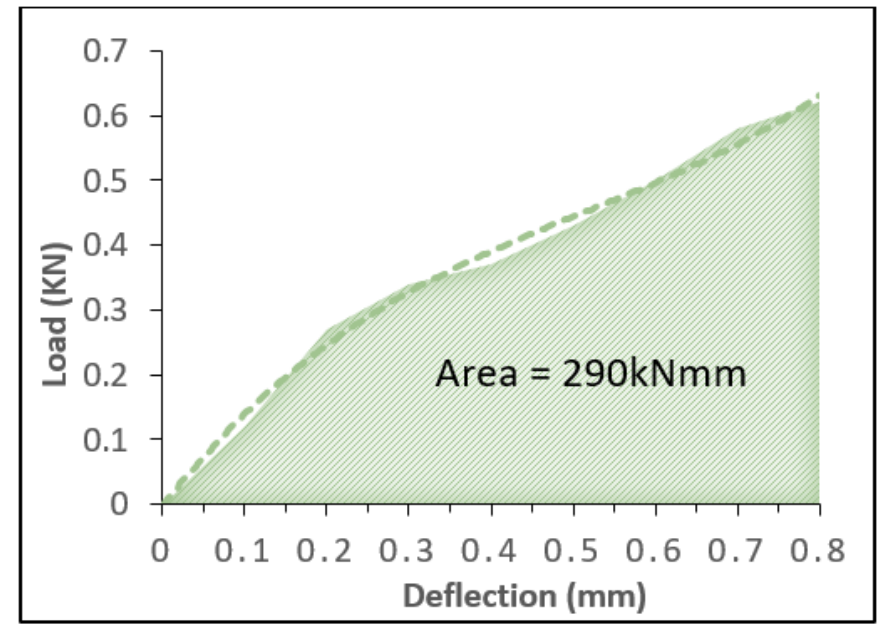

Figure 13: Load-deflection at BC $6 \% \& 1.25 \mathrm{~mm} / \mathrm{min}$.

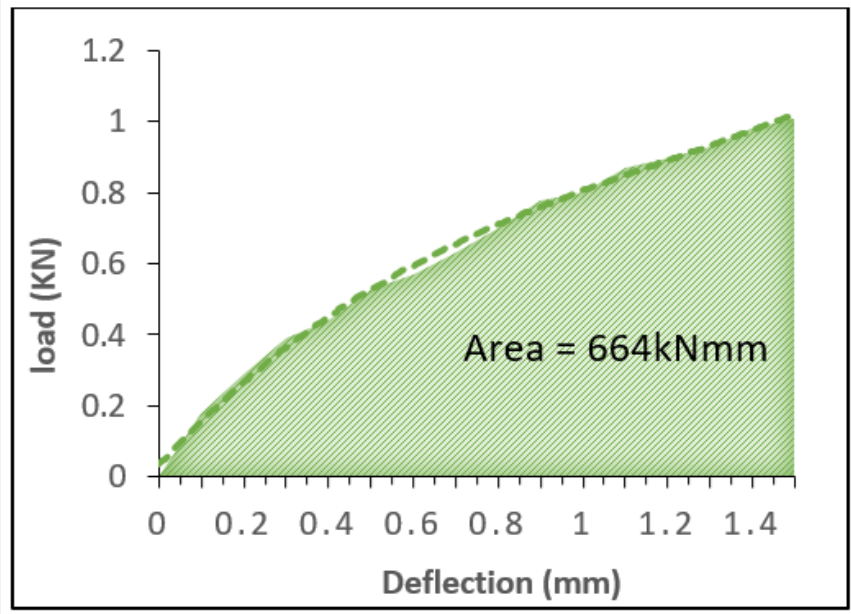

Figure 14: Load-deflection at BC $6 \% \& 1.5 \mathrm{~mm} / \mathrm{min}$.

Table 4: Fracture energy (G) for UMBC.

\begin{tabular}{|c|c|c|c|c|c|}
\hline Loading rate $(\mathrm{mm} / \mathrm{min})$ & $\begin{array}{c}\text { Bitumen Content } \\
(\%)\end{array}$ & Sample ID & $\begin{array}{l}\text { Fracture surface } \\
\text { area }\left(\mathbf{m m}^{2}\right)\end{array}$ & $\begin{array}{l}\text { Area under the curve } \\
\qquad(\mathrm{N}-\mathrm{mm})\end{array}$ & $\begin{array}{l}\text { Average Value of Ener- } \\
\text { gy (G), } J / \mathrm{m}^{2}\end{array}$ \\
\hline 1.25 & \multirow{2}{*}{4.5} & SCB 1 & 2850 & 263.5 & 92 \\
\hline 1.5 & & SCB 2 & 2850 & 627.5 & 220 \\
\hline 1.25 & \multirow{2}{*}{5} & SCB 3 & 2850 & 309.5 & 108 \\
\hline 1.5 & & SCB 4 & 2850 & 728 & 255 \\
\hline 1.25 & \multirow{2}{*}{5.5} & SCB 5 & 2850 & 285 & 100 \\
\hline 1.5 & & SCB 6 & 2850 & 662 & 232 \\
\hline 1.25 & \multirow{2}{*}{6} & SCB 7 & 2850 & 290 & 101 \\
\hline 1.5 & & SCB 8 & 2850 & 664 & 232 \\
\hline
\end{tabular}

Fracture energy of plastic modified bituminous bituminous concrete are drawn at both the rate of loadings. concrete (PMBC)

Likewise, load-deflection graph for plastic modified Afterwards, fracture energy is computed and tabulated in the Table 5. The value of fracture energy increases with increase of bitumen 


\section{Civil Engineering Research Journal}

content upto $5 \%$ at both rate of loading then after decreases. It has been observed that fracture energy at $1.5 \mathrm{~mm} / \mathrm{min}$ rate of loading is approximately 1.12 times more than $1.25 \mathrm{~mm} / \mathrm{min}$ rate of loading. However, plastic modified bituminous concrete has more ability to absorb mechanical energy in the mix than the unmodified bituminous concrete.

Table 5: Fracture energy for PMBC.

\begin{tabular}{|c|c|c|c|c|c|}
\hline Loading rate $(\mathrm{mm} / \mathrm{min})$ & Bitumen Content (\%) & Sample ID & $\begin{array}{c}\text { Fracture surface } \\
\text { area }\left(\mathrm{mm}^{2}\right)\end{array}$ & $\begin{array}{l}\text { Area under the } \\
\text { curve }(\mathrm{N}-\mathrm{mm})\end{array}$ & $\begin{array}{c}\text { Average value of } \\
\qquad \mathrm{G} \mathrm{J} / \mathrm{m}^{2}\end{array}$ \\
\hline 1.25 & \multirow{2}{*}{4.5} & SCB 1 & \multirow{2}{*}{2850} & 1013 & 355 \\
\hline 1.5 & & SCB 2 & & 1188 & 416 \\
\hline 1.25 & \multirow{2}{*}{5} & SCB 3 & \multirow{2}{*}{2850} & 1212 & 425 \\
\hline 1.5 & & SCB 4 & & 1366 & 479 \\
\hline 1.25 & \multirow{2}{*}{5.5} & SCB 5 & \multirow{2}{*}{2850} & 1141 & 400 \\
\hline 1.5 & & SCB 6 & & 1225 & 430 \\
\hline 1.25 & \multirow{2}{*}{6} & SCB 7 & \multirow{2}{*}{2850} & 1125 & 395 \\
\hline 1.5 & & SCB 8 & & 1202 & 421 \\
\hline
\end{tabular}

\section{Stress intensity factor}

The value of stress intensity factor increases as the bitumen content increases; the same result also presented by the Rodrigo et. al. [11] The result shows that fracture resistance increases with the bitumen content means chance of crack grow in bituminous concrete get decreases Table 6 . Values mentioned in the Table 7 show that as the bituminous concrete is modified with the plastic value of stress intensity factor is increased by 2 to 3 times with respect to the unmodified bituminous concrete [12-13]. The effect of loading is remained same as in the unmodified bituminous concrete means the value of stress intensity factor is increased as the loading rate increases from the $1.25 \mathrm{~mm} / \mathrm{min}$ to the $1.5 \mathrm{~mm} /$ min. Thus, the results obtained from the fracture energy concept are supported by another approach i.e. stress intensity factor.

Table 6: Stress intensity factor for UMBC.

\begin{tabular}{|c|c|c|c|c|c|}
\hline Loading rate $(\mathrm{mm} / \mathrm{min})$ & Bitumen content (\%) & Sample ID & $\begin{array}{c}\text { Maximum } \\
\text { stress }\left(\sigma^{\max }\right) \\
(\text { Mpa) }\end{array}$ & $f\left(\frac{a}{w}\right)$ & $\begin{array}{l}\text { Average value of Stress } \\
\text { intensity factor, MPa (K) }\end{array}$ \\
\hline 1.25 & \multirow{2}{*}{4.5} & SCB 1 & 0.165 & \multirow{2}{*}{1.195} & 1.1 \\
\hline 1.5 & & SCB 2 & 0.403 & & 2.7 \\
\hline 1.25 & \multirow{2}{*}{5} & SCB 3 & 0.153 & \multirow{2}{*}{1.195} & 1.2 \\
\hline 1.5 & & SCB 4 & 0.409 & & 2.74 \\
\hline 1.25 & \multirow{2}{*}{5.5} & SCB 5 & 0.233 & \multirow{2}{*}{1.195} & 1.56 \\
\hline 1.5 & & SCB 6 & 0.426 & & 2.85 \\
\hline 1.25 & \multirow{2}{*}{6} & SCB 7 & 0.432 & \multirow{2}{*}{1.195} & 2.89 \\
\hline 1.5 & & SCB 8 & 0.574 & & 3.84 \\
\hline
\end{tabular}

Table 7: Stress intensity factor for PMBC.

\begin{tabular}{|c|c|c|c|c|c|}
\hline $\begin{array}{l}\text { Loading rate } \\
(\mathrm{mm} / \mathrm{min})\end{array}$ & $\begin{array}{c}\text { Bitumen } \\
\text { content } \\
(\%)\end{array}$ & Sample ID & Maximum stress $\left(\sigma^{\max }\right)(\mathrm{MPa})$ & $f\left(\frac{a}{w}\right)$ & $\begin{array}{l}\text { Average value of Stress intensity } \\
\text { factor, } \operatorname{MPa}(\mathrm{K})\end{array}$ \\
\hline 1.25 & \multirow{2}{*}{4.5} & SCB 1 & 0.511 & \multirow{2}{*}{1.195} & 3.42 \\
\hline 1.5 & & SCB 2 & 0.568 & & 3.8 \\
\hline 1.25 & \multirow{2}{*}{5} & SCB 3 & 0.528 & \multirow{2}{*}{1.195} & 3.54 \\
\hline 1.5 & & SCB 4 & 0.596 & & 4 \\
\hline 1.25 & \multirow{2}{*}{5.5} & SCB 5 & 0.568 & \multirow{2}{*}{1.195} & 3.8 \\
\hline 1.5 & & SCB 6 & 0.704 & & 4.73 \\
\hline 1.25 & \multirow{2}{*}{6} & SCB 7 & 0.801 & \multirow{2}{*}{1.195} & 5.36 \\
\hline 1.5 & & SCB 8 & 0.647 & & 4.8 \\
\hline
\end{tabular}




\section{Civil Engineering Research Journal}

\section{Conclusion}

Total 48 semi-circular specimens were tested at different bitumen contents and loading rates. The 24 specimens were tested with the unmodified bituminous concrete. In order to check the effect of plastic modification in the bituminous concrete, the remaining specimens were prepared with plastic modified bituminous concrete. The value of fracture energy and stress intensity factor were then compared and found.

i. Value of fracture energy increases as the bitumen content increases but only up to $5 \%$, after this bitumen content the value of fracture energy start decreasing. Thus, this result shows that at intermediate temperature, the value of fracture energy is maximum at nearly optimum bitumen content in the bituminous concrete.

ii. Effect of loading rates were also checked in both unmodified and plastic modified bituminous concrete at intermediate temperature. The result shows that as the loading rate increases from 1.25 to $1.5 \mathrm{~mm} / \mathrm{min}$ the value of energy is also increased, it means that at high loading rate more energy dissipation is required to grow the crack in the bituminous concrete. The high loading represents the high speed of load passage.

iii. The modification of plastic in bituminous concrete shows that at intermediate temperature, the value of energy is increased 2 to 3 times with respect to the unmodified bituminous concrete. The result shows that modification of bituminous concrete with the plastic enhance the fracture properties of bituminous concrete i.e. fracture resistance.

iv. The fracture energy is the best fracture parameters for viscos-elastic material but in order to check the validation of the results, the value of stress intensity factor also checked. The value of stress intensity factor increases as the bitumen content increases. The value of stress intensity factor increases as the loading rate is increased from 1.25 to $1.5 \mathrm{~mm} / \mathrm{min}$.

The values stress intensity factor increases as the bituminous concrete is modified with the plastic. This result shows that more stress requires growing the crack for plastic modified bituminous concrete. The stress intensity factor supports the results obtained from energy concept.

\section{References}

1. AR (2017) Fracture resistance of asphalt concrete modified with crubber rubber at low temperature. Ahar, iran: Civil engg. department, Azad University p: 120-128.

2. Fakhria M, EH (2018) Mixed mode tensile - In plane shear fracture energy determination for hot mix asphalt mixtures under intermediate temperature condition. Tehran, Iran p: 98-113.

3. MORTH (2013) Specifications for Road and Bridge works, Fifth revision, Indian Road Congress, New Delhi pp: 3-906.

4. Nsengiyumva G (2015) Development of Semi-Circular Bending (SCB) Fracture Test for Bituminous Mixture. Lincoln: DigitalCommons@ University of Nebraska - Lincoln.

5. Siavashani AZ (2014) Development of indirect ring tension test for fracture characterization of asphalt mixture. Kentucky: University of Kentucky.

6. Some SC (2018) Numerical and experimental investigation of mode1 cracking of asphalt concrete using semi-circular bending test. construction and building material p: 34-46.

7. Stempihar J (2013) Development of the C* Fracture Test for Asphalt Concrete Mixtures. Arizona state University.

8. Ciryle S (2018) Numerical and experiemntal investigation of mpde 1 of asphalt concrete using semi-circular bending test. Construction and Building Materials p: $34-46$

9. SP:98-2013 Code of Guidelines of use of waste plastic in hot bituminious mix (Dry Process)

10. Sharma P (2017) Elements of fracture mechanics. kanpur: Mc Graw Hill.

11. Rodrigo Miró AMJ (2016) Effect of Bitumen Type and Content on the Cracking Resistance of Asphalt Mixtures at Different Temperatures. RILEM, Barcelona pp: 283-289.

12. Xu S (2016) Determination of double-K fracture paramters using semicircular bending test. Engineering fracture mechanics p: 58-71.

13. Onifade I (2015) Energy based damange and farcture framework for visco-elastic asphalt concrete. Engineering Fracture Mechanics p: $67-$ 85.

\footnotetext{
Your next submission with Juniper Publishers will reach you the below assets

- Quality Editorial service

- Swift Peer Review

- Reprints availability

- E-prints Service

- Manuscript Podcast for convenient understanding

- Global attainment for your research

- Manuscript accessibility in different formats

(Pdf, E-pub, Full Text, Audio)
}

- Unceasing customer service

Track the below URL for one-step submission https://juniperpublishers.com/online-submission.php 